\title{
MANAJEMEN SUMBER DAYA MANUSIA DI TK IT NUR AL IZHAR KEBONSARI (STUDI KASUS PENGEMBANGAN GURU)
}

\author{
Rosyida Nurul Anwar ${ }^{1}$, Alisa Alfina ${ }^{2}$ \\ 1,2 Universitas PGRI Madiun; Jl. Setia Budi No 85 Madiun, (0351) 462986

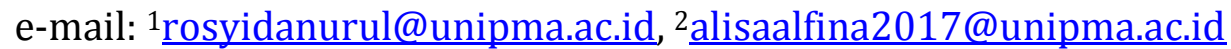

Diterima: 7 November 2019 | Direvisi: 10 Desember 2019 | Disetujui: 10 Desember 2019 (C)2019 Pendidikan Guru Raudhatul Atfhal Fakultas Agama Islam Universitas Islam Malang

\begin{abstract}
Human resource management is oriented to optimizing a working system in an organization. Kindergarten teacher development management is needed to meet the qualifications so that all teachers are able to have competence in the field of early childhood education so as to improve the quality of educational institutions, Early childhood is a golden age or golden age, so in learning kindergarten teachers do not only act as a conveyer of information to students However, teachers are required to have the ability and understand the uniqueness of each student in order to help them in various difficulties in developing creativity and learning. This research uses a qualitative approach to the type of case study. Data collection techniques carried out by observation, interviews, and documentation. Analysis of Miles and Huberman's model, namely data collection, data reduction, data presentation, and concluding become the data analysis techniques in this study. The research findings show that teacher development at TK IT Nur Al Izhar is done by coaching, counseling, mentoring, motivating, and empowering through; 1) professional training, 2) collective activities of teachers such as Clusters, IGTKI, KKG, and PGRI, 3) participation in scientific forums in the form of technical guidance, workshops, seminars, 4) mentoring the learning process.
\end{abstract}

Keywords: Human Resource, Management, Teacher Development

\section{A. Pendahuluan}

Pendidikan nasional memiliki permasalahan yang seringkali dihadapi oleh lembaga pendidikan yang bersumber dari sumber daya manusia pada guru dan karyawan pada setiap jenjang pendidikan (Mudassir, 2016). Pemerintah saat ini telah melakukan berbagai usaha untuk dapat meningkatkan sumber daya manusia yang unggul dan berkualitas, antara lain melalui berbagai pelatihan dan peningkatan kompetensi guru yang diselenggarakan pemerintah pada dinas pendidikan, perbaikan sarana prasarana pendidikan melalui bantuan dana operasional sekolah, dan peningkatan mutu manajemen sekolah.

This work is licensed under Creative Commons Attribution Non Commercial 4.0 International License Available online on: http://riset.unisma.ac.id/index.php/fai/index 
Orientasi tujuan manajemen Sumber Daya Manusia (SDM) adalah pengoptimalan suatu sistem kerja dalam sebuah organisasi dikarenakan keberadaan SDM merupakan bagian penting dan integral dalam kehidupan suatu lembaga yang pada setiap sumber daya manusianya memiliki kemampuan dan peranan yang strategis. Saat ini perlunya kesejalanan antara pendidikan dengan peradaban yang mengedepankan nilai-nilai pendidikan karakter, nilai-nilai moral yang utuh dan humanis, melestarikan kebudayaan, serta menciptakan intelektualitas yang tinggi, maka harus ditunjang dengan kualitas pendidikan dan tingginya integritas pada sumber daya manusia.

Robert L Mathis dan Jhon H. Jakson menjelaskan bahwa pada dasarnya pengembangan SDM dalam upaya merekrut, menyeleksi, menempatkan, melatih, dan mengembangkan sesuai dengan kebutuhan yang diperlukan (Krismiyati, 2019). Standar mutu kompetensi dan profesionalisme yang terjamin diperlukan dalam pembangunan pendidikan nasional. Perlunya proses pembinaan dan pengembangan berkesinambungan yang tepat sasaran dan efektif adalah dalam rangka untuk mencapai guru yang profesional yang dapat menggerakan dan memajukan dinamika pendidikan nasional. Manajemen guru juga berperan penting, karena guru adalah aktor utama yang berhadapan langsung dengan peserta didik. Kualitas seorang guru dapat menjadi tolok ukur lembaga pendidikan mampu bersaing dalam mutu dan kualitas.

Pengembangan guru TK dibutuhkan untuk memenuhi kualifikasi agar seluruh guru mampu memiliki kompetensi dibidang pendidikan anak usia dini sehingga mampu meningkatkan kualitas lembaga pendidikan anak usia dini. Hal ini sepadan dengan kebijakan pemerintah pada Undang Undang Nomor 14 tahun 2005 pasal 7 bahwa pemberdayaan profesi guru diselenggarakan melalui pengembangan diri secara demokratis, berkeadilan, tidak diskriminatif, dan berkelanjutan dengan mentikberatkan hak asasi manusia, nilai-nilai keagamaan, nilai-nilai kultural, keanekaragaman bangsa, serta kode etik profesi.

Terkait dengan penyelenggaraan Pendidikan Anak Usia Dini (PAUD) pada jalur pendidikan formal dan nonformal, lembaga PAUD seperti KB, TK, dan RA yang merupakan lembaga pendidikan Islam. Keseluruhan lembaga PAUD diselenggarakan oleh masyarakat yang membuktikan adanya peranan masyarakat untuk ikut andil dalam penyelenggaraan pendidikan nasional. Lembaga pendidikan Islam pada PAUD dikenal lebih dulu dengan RA, kemudian saat ini dikenal dengan TK Islam dan KB Islam yang penyelenggaraan layanannya mengajarkan Islam yang disesuaikan dengan kemampuan dan perkembangan anak usia dini. Dewasa ini eksistensi lembaga PAUD Islam diumpamakan seperti jamur di musim penghujan yang tumbuh subur. Dalam satu desa masyarkat dengan 
mudah menemui dua hingga empat lembaga PAUD Islam, hal tersebut menjadi suatu prestasi yang membanggakan. Akan tetapi disisi yang lain eksistensi lembaga PAUD dapat memunculkan kompetisi antar lembaga PAUD dan menimbulkan kompetensi pada pendidik dalam lembaga PAUD untuk terus meningkatakan kemampuanya agar mampu bersaing dengan pendidik-pendidik lainnya di berbagai lembaga PAUD.

Yayasan Idhafah Mutiara Amanah adalah organisasi kemasyarakatan yang menaungi TK IT Nur Al Izhar, TK ini berdiri pada tahun 2015 dan mendapatkan izin operasional pada tahun 2017, siswa yang mendaftar pada TK IT Nur Al Izhar awalnya berjumlah 18 siswa dengan jumlah 5 guru, dan sekarang berkembang pesat dengan jumlah 56 siswa dengan jumlah guru sebanyak 9 orang. Guru TK yang berstatus guru baru biasanya telah memiliki kecakapan keterampilan dasar yang dibutuhkan, namun tidak jarang pula guru baru tidak mempunyai kemampuan secara penuh dalam melaksanakan tugas-tugas pekerjaan, bahkan guru yang berpengalamanpun perlu belajar dan menyesuaikan diri dengan pendidikan meliputi organisasi, kebijakan, dan prosedurenya. Oleh sebab itu pengembangan guru diperlukan untuk mencapai hasil yang maksimal.

Angela Thomas (Azhari, 2017) mengatakan bahwa kendala-kendala yang terjadi pada pengembangan SDM diataranya:

1. Gaya manajemen yang kurang sesuai disebabkan terjadinya benturan dalam pengembangan yang dilakukan atasan yang tidak sesuai dengan bawahan sehingga menimbulkan ketegangan

2. Kurangnya motivasi untuk menguasai pengetahuan, keterampilan baru dan mendapatkan kesempatan dalam mengambil keputusan

3. Kecemasan menghadapi kegagalan

Berdasarkan uraian diatas, pengembangan guru merupakan upaya pendidikan dalam meningkatkan kualitas dan keprofesionalan guru sehingga mampu menghadapi perubahan dan dinamika pendidikan. Guna memnuhi pengembangan karir guru sebagai tenaga pendidik dan menjadi pendidik professional, seorang guru akan mendapatkan pengetahuan dan ketrampilan baru. Pengertian pengembangan karir yakni memastikan bahwa SDM dengan kualifikasi dan pengalaman yang tepat, dapat dibutuhkan kapanpun disetiap kondisi jika dibutuhkan, hal ini menjadi pendekatan formal yang dilakukan organisasi untuk pemenuhan pengembangan SDM. Pengembangan karir formal berperan penting untuk memelihara angkatan kerja yang termotivasi. Dalam pengembangan guru, TK IT Nur Al Izhar mengupayakan menjadi pendidikan yang berkualitas dengan menerapkan gaya demokratis dari kepala sekolahnya untuk dapat memberikan kebebasan pada setiap SDM yang ada dalam mengembangkan keprofesionalan 
pekerjaannya sebagai pendidik (Anwar \& Alfina, 2019), pengembangan profesionalisme guru pada TK IT Nur Al Izhar berdasarkan obeservasi yang telah dilakukan melalui berbagai kegiatan keilmiahan seperti seminar, workshop, pelatihan, juga studi lanjut pada guru yang belum memiliki kualifikasi pendidik professional atau belum bergelar sarjana.

Penelitian terdahulu relevan pada penelitian ini, diantaranya jurnal ilmiah dengan judul "Pengembangan Sumber Daya Pendidikan di Madrasah Aliyah Negeri Kabupaten Bireun" menghasilkan bahwa meningkatkan SDM pendidikan bertujuan dengan menciptakan guru yang professional dilakukan dengan pelatihan dan penataran yang intensif dan sesuai dengan kebutuhan guru (Zulhimma, 2015). Penelitian dengan judul "Pengembangan Sumber Daya Manusia dalam Meningkatkan Kualitas Pendidikan di SD Negeri Inpres Angkasa Biak" menghasilkan pelatihan SDM atau tenaga pendidik dapat meningkatkan aspeaspek kemampuan guru yang sesuai dengan tugas pokok dan fungsi yang dimiliki (Noe, 2002, p. 282). Sejalan dengan penelitian yang dilakukan oleh Riza Azhari bahwa pengembangan ketenagaan karyawan melalui proses pengembangan dan pelatihan dari aspek pengetahuan, skill, keterampilan, dan sikap (Sachdeva \& Malhotra, 2014). Hasil penelitian oleh Zulhimma menghasilkan bahwa tugas guru dalam mendidik, mengajar, membimbing, mengarahkan, melatih serta mengevaluasi merupakan tugas yang harus terus dikembangkan dengan baik agar hasil yang tercapai dapat benar-benar berkontribusi dalam peningkatan mutu pendidikan Islam (Sachdeva \& Malhotra, 2014).

Berdasarkan uraian diatas, fokus penelitian ini adalah bagaimana manajemen pengembangan guru di TK IT Nur Al Izhar Kebonsari Kabupaten Madiun.? Tujuan penelitian ini adalah untuk mengetahui secara mendalam manajemen pengembangan guru di TK IT Nur Al Izhar Kebonsari Kabupaten Madiun. Secara teoritis penelitian ini diharapkan dapat menjadi tambahan teori dan literature manajemen sumberdaya manusia. Selain itu penelitian ini diharapkan memberikan manfaat pada pengelola lembaga Pendidikan Anak Usia Dini (PAUD) untuk menjadi acuan dalam mengembangkan kemampuan SDM di lembaga PAUD. Serta dapat dijadikan acuan yang relevan bagi peneliti selanjutnya di masa yang akan datang, terutama yang berkaitan dengan manajemen sumber daya manusia PAUD.

\section{B. Metode}

Pendekatan penelitian ini adalah penelitian kualitatif, dengan jenis penelitian study kasus, yaitu menggali lebih dalam kasus-kasus yang terjadi dalam proses manajemen pengembangan sumberdaya guru di TK IT Nur Al Izhar. Kasus- 
kasus yang ditemukan kemudian deskripsikan. Lokasi penelitian ini bertempat di TK IT Nur Al Izhar beralamatkan Jl. Raya Kebonsari desa Balerejo-Kebonsari Kabupaten Madiun. Obyek penelitian adalah manajemen pengembangan sumberdaya guru PAUD, dengan jumlah guru di TK IT Nur Al Izhar sebanyak 9 orang.

Data penelitian digolongkan dalam dua jenis yaitu data primer dan data sekunder. Yang dimaksud dengan data primer ini adalah data diperoleh langsung dari narasumber sebenarnya dan pihak-pihak terkait meliputi; Kepala TK, guru dan orangtua. Sedangkan data sekunder diperoleh dari sumber-sumber lain yang atau bersifat kepustakaan melalui buku, jurnal atau sumber ilmiah lainnya. Teknik pengumpulan data dilakukan dengan cara observasi, wawancara, dan dokumentasi. Analisis model Miles dan Huberman yakni pengumpulan data, reduksi data, penyajian data, dan penarikan kesimpulan menjadi teknik Analisis data pada penelitian ini.

\section{Hasil dan Pembahasan}

Peranan strategis dalam kerangka pencapaian tujuan organisasi menjadi bagian integral dari manajemen SDM dalam pengembangan guru, secara substansi pengembangan SDM dalam arti luas dipahami sebagai proses peningkatan potensi atau kemampuan, kompetensi dan karir karyawan yang bersangkutan. Pengembangan guru merupakan kesempatan belajar untuk membantu guru dapat berkembang dalam jangka panjang. Menurut Noe, pengembangan dapat diperoleh melalui pendidikan secara formal, pengalaman kerja, hubungan interpersonal atau penilaian personality dan pengembangan tidak harus berkaitan dengan tugas saat ini (Sudarmanto, 2009, p. 242).

Perencanaan pengembangan SDM pada TK IT Nur Al Izhar merupakan upaya yang dilakukan sekolah dalam menyiapkan keputusan yang berkaitan dengan program-program dalam pelaksanaan pengembangan guru. Pada proses perencanaannya dilakukan dengan beberapa tahapan yaitu, pertama analisis kebutuhan pengembangan yaitu melihat dan mngetahui apa yang sekiranya dibutuhkan guru dengan berbagai hal yang meliputi kekuatan dan kelemahan serta peluang program tersebut. Kedua, penentuan tujuan pengembangan, hal ini dilaksanakan setelah kiranya program pengembangan telah terindetifikasi melalui musyawarah penentuan kepala sekolah dengan guru di TK IT Nur Al Izhar. Hal ini sesuai dengan pendapat Leonard Nadler bahwa pengembangan SDM dilakukan dalam waktu tertentu dan dirancang untuk melahirkan perubahan sikap karyawan yang menjadi sebuah rangkaian aktivitas pada sebuah perusahaan (Purnama \& Ikatrinasari, 2018). 
Pada pengembangan SDM dibutuhkan adanya strategi pengembangan yang merupakan salah satu cara atau teknik yang dilakukan TK IT Nur Al Izhar untuk meningkatkan kualitas dan kuantitas SDMnya. Strategi pengembangan disusun dengan mengacu pada hasil analisis kebutuhan pengembangan di PAUD. Setelah dilakukan penelitian pada TK IT Nur Al Izhar, diketahui bahwa pengembangan guru didesain untuk membantu guru berkembang. Fokus pengembangan adalah jangka panjang dan untuk membantu guru mempersiapkan masa depan. Manajemen pengembangan guru di TK IT Nur Al Izhar dilakukan dengan melibatkan seluruh anggota sekolah dan dilakukan dengan bentuk coaching, counseling, mentoring, motivating, dan empowering.

\section{Coaching (Pembinaan)}

Coaching (Pembinaan ) adalah "the practice of giving sufficient direction, instruction and training to a person or a group people, so as to achieve some goals or even in developing specific skills" (Yasin, 2011, p. 10). Coaching (Pembinaan) adalah praktik memberikan arahan, instruksi, dan pelatihan yang memadai kepada seseorang atau sekelompok orang, sehingga dapat mencapai beberapa tujuan dalam mengembangkan keterampilan khusus. Coaching merupkan pembinaan yang dilakukan oleh seorang atas atau manajer kepada bawahannya sebagai perbaikan kinerja.

Pembinaan guru di TK IT Nur Al Izhar dilakukan oleh kepala sekolah dalam kerangka perbaikan kinerja guru serta pengembangan profesionalisme guru. Berdasarkan hasil wawancara dengan Kepala TK IT Nur Al Izhar, pembinaan kepada guru dengan mendasarkan pada problem kinerja atau tidak mampu mencapai target kinerja yang ditargetkan. Sebagai contoh dari hasil penilaian kinerja guru, beberapa guru tidak mencapai target dalam membaca Al Quran dengan baik menggunakan metode Wafa' sedangkan metode inilah yang akan diajarkan oleh siswa, maka TK IT Nur Al Izhar mengadakan pembinaan dengan pelatihan membaca AlQuran metode wafa kepada seluruh guru dengan mendatangkan dan mengikuti kelas khusus pada pelatihan tersebut.

Coaching sebagai metode mengarahkan, menginstruksikan dan melatih guru atau dengan tujuan untuk mencapai beberapa tujuan atau mengembangkan keterampilan khusus. Selain pelatihan metode Wafa' dalam mengembangkan keterampilan guru TK IT Nur Al Izhar juga mengadakan pelatiha yang bekerjasama dengan badan usaha ang bergerak dibidang seni yaitu menggambar. Keterampilan guru menggambar menimbulkan kreatifitas guru yang berdampak pada meningkatnya pengetahuan peserta didik dalam menggambar bahkan beberapa 
guru di TK IT Nur Al Izhar telah mampu membuat buku bergambar hasil karya dari pelatihan tersebut.

Manfaat kepala sekolah dalam pelaksanaan pembinaan adalah memiliki tim atau guru yang kuat sehingga menjadi investasi masa depan pada lembaga pendidikan di TK IT Nur Al Izhar khususnya, hal tersebut sejalan dengan pendapat Gallwey bahwa dalam memaksimalkan kinerja, coaching menjadi sebuah proses membuka kunci potensi seseorang (Yuliawan, 2011).

\section{Counselling (konseling)}

Counselling (konseling) adalah "the process of communicating to an employee the manager's assessment of the strong aspects of the employee's performance of jobs and ways in which that performance may be improved" (Mudassir, 2016). Konseling adalah proses mengkomunikasikan kepada karyawan mengenai bagaimana penilaian manajer tentang aspek-aspek kuat dari kinerja pekerjaan karyawan dan cara-cara di mana kinerja itu dapat ditingkatkan. Dengan kata lain, konseling sebagai upaya dalam membantu guru untuk memahami dan memecahkan masalahnya sendiri. Tujuan daripada konselling menurut Dale (dalam Sudarmanto) adalah:

1. Untuk memperoleh pemahaman mengenai seseorang secara lebih baik

2. Untuk membuat keputusan penting secara pribadi

3. Untuk menetapkan tujuan yang dapat dicapai secara pribadi

4. Untuk menyusun solusi masalah pribadi maupun antarpribadi secara efektif

5. Untuk menghadapi lingkungan yang sulit

6. Untuk menghadapi emosi pribadi yang negative

Dalam menyikap pelaksanaan konselling, TK IT Nur Al Izhar memiliki konsultan pendidikan yang khusus memenuhi dan membantu permasalahan yang ada di sekolah terutama yang berkaitan dengan peningkatan kualitas sekolah dalam hal ini adalah seluruh komponen sekolah. Fungsi daripada konsultan di sekolah ini adalah untuk memberikan solusi terhadap permasalahan guru baik itu pribadi maupun antar pribadi.

Konseling adalah kemampuan melaksanakan komunikasi sebagai orang yang mampu berpikir dengan nalar yang sehat sebagai sendi untuk membangkitkan empati secara lahariah untuk menerapkan ilmu dalam mewujudkan nilai dan ganjar dalam perubahan kehidupan. Peran konseling juga diterapkan oleh guru sebagai usaha dalam proses pembelajaran dan pendiikan pada peserta didik, setiap pendidik harus mampu berperan sebagai konselor yang dapat memenuhi harapan anak sehingga mampu meberikan motivasi dan bimbingan pada anak. 


\section{Mentoring (Pendampingan)}

Mentoring sebagai usaha yang bertujuan memberikan wawasan dalam mengembangkan karyawan. Pendampingan melibatkan empati, saling berbagi pengalaman, persahabatan secara professional dan saling, mengembangkan wawasan melalui refleksi. Mentoring lebih memiliki jangkauan pekerjaan yang lebih lama, karena yang diperbaiki bukan sekedar membangun kinerja, tetapi juga keseluruhan hidup yang dimentor. Pendampingan berasal dari kata kerja "mendampingi". Istilah pendampingan yang pada awalnya disebut "pembinaan". Manajemen pendampingan guru adalah suatu program yang diterapkan di sekolah dalam rangka meningkatkan kompetensi profesional guru dengan cara memberikan bimbingan (Argawinata, 2016).

Pelaksanaan mentoring di TK IT Nur Al Izhar menekankan pada pendampingan ibadah dan pencapaian hasil belajar siswa. Program pendampingan meliputi pendampingan proses belajar mengajar, pendampingan penulisan buku, pendampingan studi banding ke sekolah-sekolah dengan tujuan meningkatkan sistem dan manajemen pada proses pembelajaran. Pendampingan ibadah dalam hal ini adalah bagaimana guru diberikan pemahaman dan pelatihan dan dibimbing dalam pelaksanaan ibadah disekolah maupun di rumah. Ketika guru hadir disekolah pukul 07.00 diminta untuk melaksanakan sholat dhuha dan membaca al Quran terlebih dahulu. Pendamping di sekolah tersebut memiliki peran: (1) memecahkan masalah, pendamping sebagai pemberi solusi dan bukan sebagai bagian dari masalah, (2) pendamping sebagai pemberi umpan balik dalam meningkatkan kinerja, (3) pendamping sebagai bagian dari mengembangkan orang lain, dan (4) pendamping sebagai guru dan pengarah.

\section{Motivating (Motivasi)}

Dalam lingkungan pekerjaan seringkali dijumpai permasalahan seseorang mengalami demotivasi, sehingga mengakibatkan kinerja organisasi turun. Demotivasi karyawan terjadi dikarenakan beberapa kemungkinan, yaitu;

1. Secara penghasilan, karyawan belum mendapatkan yang sepadan dengan kinerja yang telah diberikan

2. Adanya karir yang tersumbat atau seseorang belum memiliki jabatan sesuai diharapkan

3. Kompetensi seseorang dibawah standar persyaratan, sehingga mengalami kesulitan dalam menyelesaikan pekerjaan.

Dalam memanajemen SDM, TK IT Nur Al Izhar memiliki cara motivasi sendiri dalam mengatasi kemungkinan adanya demotivasi. Menurut kepala sekolah TK IT Nur Al Izhar guru terkadang menurun kinerja jika hanya terfokus 
pada penghasilan dikarenakan penghasilan yang diperoleh tidak sebanyak pekerjaan diluar selain guru TK, sebagai upaya memberikan dorongan terhadap permasalahan tersebut kepala sekolah memnyampaikan motivasinya bahwa pekerjaan yang dilaksanakan haruslah bermuara pada Tuhan Yang Maha Esa, sebagai pemberi rezeki dan semata-mata pekerjaan dilakukan hanya mengharapkan ridho Allah dan sebagai ibadah amal perbuatan. Hadist nabi yang diriwayatkan oleh Abu Hurairah “...dan seorang laki-laki yang belajar dan mengajarkan ilmu serta membaca Al Qur'an, lalu dia didatangkan dan Allah mengingatkan nikmat-nikmatNya (kepadanya) dan dia pun mengenalnya". Selain daripada itu, faktor demotivasi pada lembaga pendidikan ini dikarenakan adanya kejenuhan yang dialami guru dan karyawan pada aktifitas keseharian disekolah, pembelajaran yang dihadapkan pada peserta didik, atau perangkat dan bahan pembelajaran yang tiap harinya harus dipersiapkan. Dalam menangani permasalahan ini yayasan memiliki peranan penting dengan memberikan arahan dan nasehat akan pentingnya menggerakkan fikiran dan anggota badan kearah positif (positive thinking) sehingga kejenuhan yang dirasa tidak membutuhkan waktu lama dan berlarut-larut sehingga mengakibatkan menurunnya kinerja secara professional. Dalam hal ini, memotivasi karyawan dapat dilakukan dengan mestimulasi karyawan melalui kebuthan-kebutuhan yang belum terpuaskan (Triton, 2010, p. 161). Motivasi diperlukan oleh para professional dan wirausahawan dikarenakan adanya keterlibatan dan dihadapkan pada orangorang dalam aktivitas sehari-hari.

\section{Empowering (Pemberdayaan)}

Michael Osbaldeston (Noe, 2002, p. 282) menyatakan bahwa pentingnya pemberdayaan dikarenakan kecepatan perubahan semakin tinggi, organisasi terus berubah, organisasi menuntut kerja lintas studi, bakat manajerial yang bagus dianggap langka dan mahal. Pemberdayaan menjadi suatu dorongan dan menungkinkan individu untuk memperbaiki cara pelaksanaan pekerjaannya. Pemberdayaan diperlukan dikarenakan dalam meningkatkan kemampuan, tidak semua guru dapat melakukannya. Begitu juga dalam merespons perkembangan dan isu dinamis terkait dunia pendidikan, perkembangan ilmu pengetahuan teknologi dan tuntutan masyarakat banyak para guru belum mampu memahaminya (Forefry, 2017). Menurut Suhartono, masyarakat yang berdaya menjadi tujuan dari pemberdayaan pada hasil yang ingin dicapai pada perubahan sosial. Dalam pengembangan guru, TK IT Nur Al Izhar memberdayakan gurunya melalui berbagai kegiatan yaitu seperti mengikuti kegiatan kolektif guru seperti GUGUS, IGTKI, KKKS. Hasil temuan dalam pengembangan guru di TK IT Nur Al 
Izhar juga memiliki banyak faktor dalam mempengaruhi pemberdayaan guru disekolah yakni kepemimpinan kepala sekolah, iklim kerja, budaya sekolah dan sarana prasarana. Kepemimpinan kepsala sekolah menjaid yang paling dominan dalam hal: (pengawasan lingkungan kerja, kebijakan teknis, perencanaan, pelaksanaan program kerja lembaga, dan dampak).

Berdasarkan Undang-Undang Republik Indonesia Nomor 20 Tahun 2003 tentang Sistem Pendidikan Nasional; Undang Undang Republik Indonesia Nomor 14 Tahun 2005 tentang Guru dan Dosen; dan Peraturan Pemerintah Republik Indonesia Nomor 19 Tahun 2005 tentang Standar Nasional Pendidikan menyatakan bahwa guru adalah pendidik profesional. Untuk itu, dipersyaratkan guru memiliki kualifikasi akademik minimal sarjana atau diploma IV yang relevan, dan menguasai kompetensi sebagai agen pembelajaran. Berdasarkan hal tersebut pemberdayaan guru juga dilaksanakan adalah studi lanjut. Guru di TK IT Nur Al Izhar memiliki 1 guru yang sedang studi lanjut strata 1 dan diharapkan dengan melanjutkan studi lanjut kualitas pendidikan di TK semakin berkualitas dan dalam pengembangannya guru diberdayakan.

\section{Simpulan}

Temuan hasil penelitian ini adalah manajemen pengembangan guru di TK IT Nur Al Izhar didesain untuk membantu guru berkembang. Fokus pengembangan adalah jangka panjang dan untuk membantu guru mempersiapkan masa depan. Manajemen pengembangan guru di TK IT Nur Al Izhar dilakukan dengan melibatkan seluruh anggota sekolah dan dilakukan dengan bentuk coaching, counseling, mentoring, motivating, dan empowering.

1. Coaching, pembinaan kepada guru dilakukan dalam kerangka perbaikan kinerja guru serta pengembangan profesionalisme guru, pembinaan dengan mendasarkan pada problem kinerja atau ketidakmampuan guru dalam mencapai target kinerja yang ditargetkan.

2. Counseling, konsultan pendidikan memiliki peranan khusus dalam memenuhi dan membantu permasalahan yang ada di sekolah yang berkaitan dengan peningkatan komponen pendidikan dan kualitas sekolah, dalam hal ini memberikan solusi terhadap permasalahan guru baik itu pribadi maupun antar pribadi.

3. Mentoring, Penekanan pendampingan pada sekolah meliputi pendampingan dalam ibadah dan pencapaian hasil belajar siswa. Pendampingan proses belajar mengajar, pendampingan penulisan buku, pendampingan studi banding ke sokolah-sekolah menjadi kegiatan pendampingan dengan tujuan meningkatkan sistem dan manajemen yang mendorong proses pembelajaran 
dan pendidikan sekolah yang baik. Pendampingan ibadah berupa pemahaman dan pelatihan dalam pelaksanaan ibadah yang dikhusukan untuk ibadah peserta didik.

4. Empowering, faktor pemberdayaan disekolah meliputi kepemimpinan kepala sekolah, iklim kerja, budaya sekolah dan sarana prasarana. Kegiatan pemberdayaan berupa kebijakan teknis, perencanaan, pelaksanaan, pengawasan dan dampak juga pelasanaan kegiatan kolektif guru.

\section{Daftar Rujukan}

Anwar, R. N., \& Alfina, A. (2019). Kepemimpinan Kepala Sekolah Dalam Pengembangan Profesionalisme Guru Di TK IT Nur Al Izhar Kebonsari. Prosiding Conference on Research and Community Services, 51-56. Jombang: STKIP PGRI Jombang.

Argawinata, A. Z. (2016). Manajemen Pendampingan Guru Untuk Meningkatkan Kompetensi Pedagogik Dan Profesional Guru-Guru Mata Pelajaran Sekolah Menengah Pertama Di Kota Bandung. Jurnal Imiah Mitra Swara Ganesha, 3(1), 1-16.

Azhari, R. (2017). Manajemen Pembinaan Karir Sumber Daya Manusia dalam Pendidikan Islam. At-Ta'dib, 12(2), 71. https://doi.org/10.21111/attadib.v12i2.1166

Forefry, N. (2017). Strategi Pemberdayaan Guru Oleh Sekolah (Studi Kasus di SMAN 5 dan SMA Darul Hikam Kota Bandung). Jurnal Administrasi Pendidikan, XXIV(1), 47-59.

Krismiyati. (2019). Pengembangan Sumber Daya Manusia dalam Meningkatkan Kualitas Pendidikan di SD Negeri Inpres Angkasa Biak. Jurnal Office, 3(1), 43. https://doi.org/10.26858/jo.v3i1.3459

Mudassir. (2016). Pengembangan Sumber Daya Pendidikan Di Madrasah Aliyah Negeri (MAN) Kabupaten Bireun. Jurnal Ilmiah DIDAKTIKA, 16(2), 255-272.

Noe, R. A. (2002). Employee Training \& Development. New York: McGraw Hill.

Purnama, G. N. T., \& Ikatrinasari, Z. F. (2018). Pengembangan Sdm Untuk Meningkatkan Kinerja Terkait Keselamatan Kerja. Jurnal Inkofar, 1(1), 3948.

Sachdeva, S., \& Malhotra, K. (2014). Motivating Students - Essentials of Mentoring , Coaching \& Counseling: Operational Strategy. 2(2), 273-300. https://doi.org/10.15415/iie.2014.22020

Sudarmanto. (2009). Kinerja dan Pengembangan Kompetensi SDM. Yogyakarta: Pustaka Pelajar. 
Rosyida Nurul Anwar, Alisa Alfina

Triton. (2010). Manajemen Sumber Daya Manusia: Perspektif Partnership dan Kolektivitas. Jakarta: Oryza.

Yasin, A. F. (2011). Pengembangan Sumber Daya Manusia di Lembaga Pendidikan Islam. Malang: UIN Malang Press.

Yuliawan, T. P. (2011). Coaching Psychology: Sebuah Pengantar. Buletin Psikologi, 19(2), 45-54.

Zulhimma. (2015). Upaya Peningkatan Kompetensi Guru Dalam Meningkatkan Mutu Pendidikan Islam. Jurnal Tarbiyah, 22(2), 347-368. 